\title{
PELATIHAN TENUN DARI LIMBAH LIDI KELAPA SAWIT DENGAN MENGGUNAKAN ATBM BAGI REMAJA DI KABUPATEN ACEH TAMIANG
}

\author{
Zulkarnen Mora $^{1 *}$, Abdul Latief ${ }^{1}$, Zainuddin ${ }^{2}$ \\ ${ }^{1}$ Fakultas Ekonomi, Universitas Samudra, Langsa, Indonesia \\ ${ }^{2}$ Fakultas Hukum, Universitas Samudra, Langsa, Indonesia \\ "Penulis Korespodensi : zulkarnen.mora@gmail.com
}

\begin{abstract}
Abstrak
Tujuan Kegiatan pengabdian kepada masyarakat (PKM) Pelatihan tenun dari limbah lidi kelapa sawit dengan menggunakan Alat Tenun Bukan Mesin (ATBM) bagi remaja di Kabupaten Aceh Tamiang ini adalah untuk melatih naluri kewirausahaan (entrepreneurship) dengan berbasis kepedulian lingkungan para remaja putri yang putus sekolah dan yang aktif sekolah yang berdomisili sekitar kawasan perkebunan kelapa sawit. Lokasi pelatihan dipilih berdasarkan pertimbangan kawasan tempat tinggal yang berdekatan dengan kebun kelapa sawit PT. Mapoli Raya Aceh Tamiang dan juga kebun milik warga yang terdapat di Kampung Paya Bedi, Kecamatan Rantau-Kabupaten Aceh Tamiang. Jumlah peserta yang telibat dalam kegiatan ini adalah 10 orang di mana 6 remaja putri yang tidak melanjukan lagi sekolah dan ditambah 4 orang yang masih sekolah yang memiliki minat untuk ambil bagian dalam pelatihan tenun ini. Metode pelatihan yang diterapkan dalam pelatihan tenun ini apprenticeship yaitu dengan cara memberikan bimbingan dan langsung mengerjakan, melakukan pendampingan dalam jangka mono tahun serta membantu kelompok karya muda untuk melakukan chanelling pemasaran (marketing chanell). Tahapan kegiatan pelatihan dibagi kedalam empat tahap, dengan jadwal yang telah disepakati oleh peserta, pemateri dan mitra dalam hal ini kelompok karya muda kampung Paya Bedi. Kegiatan dimulai dengan sosialisasi kepada warga, perangkat kampung dan peserta yang dilaksanakan pada tanggal 4 Agustus 2017. Selanjutnya pelatihan perdana dijalankan pada tanggal 5 Agustus 2017 dengan materi optimalisasi penggunaan ATBM kelompok yang dilatih oleh Zulkarnen Mora; pelatihan kedua dilaksanakan pada tanggal 6 Agustus 2017 dengan materi Pelatihan tenun limbah lidi kelapa sawit dengan menggunakan ATBM yang diampaikan oleh Abdul Latief; serta diakhiri kegiatan pada tanggal 7 Agustus 2017 dengan materi Penguatan manajemen organisasi dan keuangan kelompok perempuan karya muda yang disajikan oleh Zainuddin sekaligus melakukan closing ceremony dengan peserta dan mitra. Hasil yang dicapai di mana peserta yang notabenenya adalah remaja putri telah mampu dan memahami arti penting manfaat lingkungan bagi peningkatan pendapatan keluarga dengan menghasilkan aneka ragam produk yang diolah dari limbah lidi kelapa sawit menjadi sovenir yang bernilai jual dan artistik seperti dompet wanita, kotak stationery, kotak tisu dan lain sebagainya. Simpulannya, pelatihan ini sangat membantu remaja dalam membuka cakrawala berpikir dan sense of belonging mereka terhadap keberadaan lingkungan (limbah lidi kelapa sawit) dalam menciptakan peluang usaha yang terintegrasi dengan minat wirausaha yang perlu ditanam sejak dini untuk mencapai kesejahteraan yang lebih baik dalam menghadapi tantangan global di masa yang akan datang.
\end{abstract}

Kata Kunci : Pelatihan Tenun, Limbah Kelapa Sawit, remaja putri, kelompok karya muda

\begin{abstract}
The purpose of Community Service Activities (PKM) Training of weaving from palm oil palm waste using Non-Engine Weaving Tool (ATBM) for adolescents in Aceh Tamiang District is to train entrepreneurial instinct (entrepreneurship) with environmental-based awareness of girls dropping out of school and an active school domiciled around the oil palm plantation area. The training location was chosen based on consideration of the residential area adjacent to the oil palm plantation of PT. Mapoli Raya Aceh Tamiang and also owned by residents garden in Kampung Paya Bedi, District of Rantau-Kabupaten Aceh Tamiang. The number of participants involved in this activity is 10 people where 6 teenage girls are no longer school and plus 4 people still in school who have an interest to take part in this weaving training. The training method applied in this weaving training is apprenticeship by providing guidance and direct work, perform mentoring in mono-year and help young work group to do marketing chanelling. The stages of the training activities are divided into four stages, with the schedule agreed by the participants, the presenters and partners in this case the
\end{abstract}


young work group of Paya Bedi village. The activity began with socialization to the villagers, villagers and participants held on August 4, 2017. Furthermore, the initial training was conducted on 5 August 2017 with material optimization of the use of ATBM group trained by Zulkarnen Mora; the second training was conducted on August 6, 2017 with training material of palm oil palm waste weaving using ATBM delivered by Abdul Latief; and ended the activity on August 7, 2017 with material Strengthening management organization and financial group of young women works presented by Zainuddin as well as closing ceremony with participants and partners. The results achieved in which participants who are notabenenya young women have been able and understand the importance of environmental benefits for the increase in family income by producing a variety of products processed from palm oil palm waste into souvenirs worth selling and artistic such as women's wallets, stationery boxes, boxes tissues and so forth. In conclusion, this training helps teenagers to open their horizons of thinking and sense of belonging to the existence of the environment (palm oil palm waste) in creating business opportunities integrated with entrepreneurial interests that need to be planted early to achieve better prosperity in facing global challenges at future.

Keywords: Weaving Training, Palm Oil Waste, Young Women, Young Working Group

\section{PENDAhuluan}

\subsection{Analisis Situasi}

Aceh Tamiang merupakan salah satu kabupaten yang terdapat di wilayah Provinsi Aceh, Indonesia. Kabupaten ini sangat dikenal sebagai daerah yang kaya akan hasil alamnya seperti gas alam, minyak dan hasil perkebunannya yang melimpah. Jika kita tinjau lebih mendalam di kawasan ini banyak dijumpai puluhan industri yang bergelut dibidang perkebunan diantaranya kelapa sawit, aren, sagu dan karet. Sebagai main gate dari Provinsi Sumatra Utara menuju ibukota Provinsi Aceh, Dengan luas daerah lebih kurang 1.957,02 $\mathrm{km}^{2}$, Aceh Tamiang ini menyuguhkan potensi alam yang cukup menjanjikan. Wilayah teritorialnya terbagi ke dalam 12 kecamatan, dan salah satu dari kecamatan tersebut memiliki keunggulan khusus yaitu kecamatan Rantau.

Kecamatan Rantau memiliki luas wilayah 75,44 KM ${ }^{2}$ dan terdiri dari 16 kampung yang menaunginya (www.lintasatjeh.com). Salah satu kampung yang merupakan bagian dari kecamatan ini yaitu Kampung Paya Bedi. Kampung ini memiliki luas wilayah 192 Ha yang terdiri dari 34 Ha lahan sawah, 78 Ha lahan ladang dan 80 perkebunan rakyat (BPS, 2014). Mengingat luas areal perkebunan yang sangat mendominasi, hal ini menunjukkan kepada kita bahwa di samping terdapat areal perkebunan yang dimiliki oleh perusahaan swasta (PT, Mapoli Raya), masyarakatnya juga sangat tertarik dengan usaha perkebunan kelapa sawit.

Walaupun kita ketahui bahwa tumbuhan kelapa sawit ini hanya menghasilkan Crued Palm Oil (CPO) saja namun disebalik itu tanaman ini juga dikenal dengan tanaman multi guna. Artinya tanaman ini ternyata tidak lagi jadi ancaman kepada petaninya atau masyarakat yang tinggal di sekitar areal perkebunan kelapa sawit dengan limbah yang dihasilkannya seperti pelepah, daun dan batang yang sudah tua atau semak. Di beberapa daerah lain seperti di pulau jawa dan sumatra utara, limbah lidi kelapa sawit ini sudah dapat dimanfaatkan sebagai produk kerajinan tangan yang bernilai ekonomis. Dengan keahlian yang dimiliki oleh sumber daya manusianya limbah lidi kelapa sawit (Elaeis Guineensis Jacq)ini sudah dapat diolah menjadi aneka produk hiasan, fasion dan perlengkapan rumah tangga seperti vas bunga, sarung lampu patromat, dompet dan tas wanita, pirieng lidi pada rumah makan ayam penyet dan lain sebagainya.

Demikian juga halnya yang terjadi pada kampung Paya Bedi di Kecamatan Rantau ini, sekelompok ibuibu rumah tangga dan remaja putri melihat ini sebagai peluang untuk menghasilkan produk kerajinan tangan dengan memanfaatkan limbah lidi kelapa sawit yang ada di lingkungan tempat tinggal mereka. Kreativitas ini tidak lahir begitu saja, tentunya ada banyak pihak yang terlibat dalam mengelola limbah kelapa sawit ini. Sebut saja pemerintah kabupaten Aceh Tamiang melalui dinas terkait memberikan bantuan yang bersifat moril dan spirituil kepada warga. Di tambah lagi perusahaan BUMN seperti PT. Pertamina EP Rantau juga tidak tinggal diam untuk memberikan berbagai pelatihan dan donasi dalam bentuk peralatan kerja untuk mendukung terbentuknya satu kelompok usaha yang diprakarsai oleh kaum hawa di kampung Paya Bedi tersebut. Tak kalah penting juga peran lembaga swadaya masyarakat LP2K dalam mempercepat kematangan pembentukkan organisasi kelompok menjadi organisasi bisnis.

Berdasarkan hasil observasi dan juga data yang diperoleh saat ini di Kampung Paya Bedi sudah ada kegiatan usaha yang dilakukan oleh Bapak dan Ibu yang tergabung ke dalam kelompok anyaman tepas Karya Muda Kampung Paya Bedi Kecamatan Rantau Kabupaten Aceh Tamiang. Dimana mereka kebanyakan hanya berpendidikan hingga tingkat SMP dan SMA dan bekerja sebagai buruh pada perkebunan kelapa sawit swasta PT MOPOLI RAYA. Penghasilan sebagai buruh harian lepas menyebabkan tidak terpenuhinya kebutuhan harian keluarga dan pendidikan anak-anak mereka hingga tingkat perguruan tinggi. 
Sebelumnya kelompok karya muda merupakan salah satu kelompok pengrajin yang terdapat di kampung Paya Bedi, kabupaten Aceh Tamiang. Kelompok ini didirikan pada bulan september 2013. Diawal pendiriannya kelompok ini memiliki 9 orang anggota kelompok yang kesemuannya adalah ibu rumah tangga. Saat ini kelompok karya muda sudah mulai berkembang dengan memiliki anggota lebih dari 40 orang. Saat ini kelompok telah memiliki beberapa peralatan kerja bantuan dari Dinas sosial dan tenaga kerja kabupaten Aceh Tamiang berupa satu unit mesin raut yang dipergunakan untuk membuat anyaman tepas dari pelepah kepala sawit yang tak terpakai.

Keberadaan kelompok wanita ini menjadi landasan pacu bagi kampung ini untuk menggantungkan citacita sebagai kampung unggul menjadi one product one village. Walaupun kelompok Karya Muda ini hanya memiliki 2 unit ATBM bantuan dari salah satu lembaga pendamping yang selama ini melakukan assistensi kepada kelompok tersebut. Namun keberadaan kelompok ini dirasakan masih kurang kontributif terhadap masyarakat sekitarnya. Dengan kata lain kelompok ini belum secara optimal mampu memanfaatkan kekuatan sumber daya manusia potensial yang tersedia disekitar mereka seperti keberadaan remaja-remaja kampung yang putus sekolah maupun dalam masa pendidikan (paruh waktu). Oleh karena itu, tim pendamping dari Universitas Samudra termotivasi untuk menggagas untuk mengoptimalkan pemanfaatan limbah lidi kelapa sawit dengan melakukan penenunan dengan ATBM. Adapun produk-produk tenun yang akan dihasilkan nantinya antara lain: kotak tisu, kotak aksesoris, kotak alat tulis kantor, tas dan dompet wanita dan lain-lain yang bernilai jual tinggi.

Kesempatan melatih remaja putri yang putus sekolah merupakan sesuatu yang tidak mudah disebabkan generasi muda sekarang telah dihinggapi satu keadaan yang apatis/ sikap cuek terhadap lingkungan. Hal ini juga sangat dipengaruhi oleh dampak negatif perkembangan jaringan internet yang bebas lepas kontrol oleh orang tua serta juga dipengaruhi oleh budaya asing yang mudah ditiru layaknya pergaulan bebas dan penggunaan zat aditif lainya.

Oleh karena itu perlu untuk disikapi bahwa untuk terhindar dari marabahaya yang suram bagi para remaja putri ini maka sangat diperlukan sekali perhatian dari berbagai instansi baik pemerintah daerah, BUMN, Perusahaan Swasta dan pemerintah kampung serta Perguruan Tinggi baik secara individual maupun secara kolaboratif untuk memberikan pelatihan dengan memanfaatkan limbah kelapa sawit yang ada di sekitar mereka. Berkenaan dengan hal tersebut tim pengabdian dari Lembaga Penelitian, Pengabdian dan Penjaminan Mutu (LPPM \& PM) Universitas Samudra perlu melakukan satu model pelatihan tenun limbah lidi kelapa sawit dengan menggunakan ATBM kepada remaja di Kabupaten Aceh Tamiang.

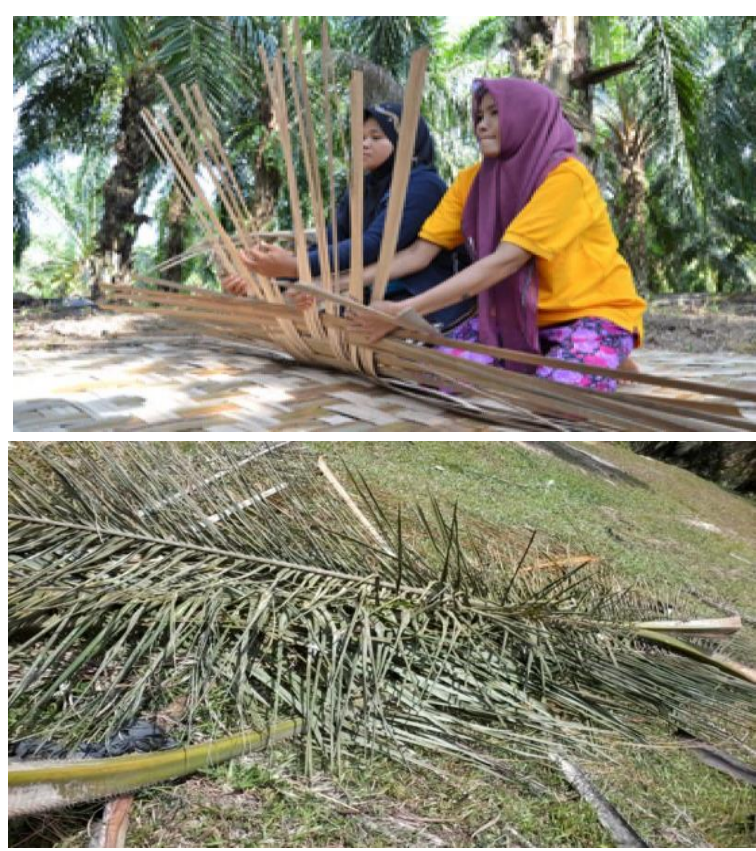

Gambar. 1. Limbah kelapa sawit dan Kelompok karya muda sedang mengayam tepas dari Kelapa Sawit

\subsection{Permasalahan Utama Mitra}

Mitra dalam kegiatan ini adalah kelompok perempuan karya muda, Kampung Paya Bedi, Kab. Aceh Tamiang. Permasalahan yang dihadapi oleh kelompok perempuan Karya Muda sebagai mitra adalah :

a. Belum optimalnya pemanfaatan alat tenun bukan mesin (ATBM) oleh kelompok tersebut

b. Remaja yang berdomisili di kampung paya bedi dan sekitar tidak mengetahui cara mengolah limbah lidi sawit melalui ATBM

c. Limbah lidi kelapa sawit saat ini hanya dimanfaatkan untuk membuat aneka produk kerajinan tangan

d. Lemahnya manajemen kelompok perempuan Karya Muda terutama dari aspek pencatatan administrasi bisnis dan keuangan kelompok

Diperlukan beberapa solusi untuk dapat menyelesaikan permasalahan yant telah teridentifikasi agar usaha yang dijalankan oleh kelompok perempuan karya muda ini dapat berjlan dengan baik. Oleh karena itu perlu mengambil langkah untuk mempersiapkan solusi atau penyelesaian masalah yang dihadapi oleh kelompok karya muda dan remaja putri sekaligus sebagai aset sumber daya manusia yang ada di kampung tersebut secara berkesinambungan pada masa yang akan datang antara lain:

a. Memberikan Optimalisasi penggunaan alat tenun bukan mesin (ATBM) oleh kelompok dari penerima manfaat lainnya 
b. Pelatihan pembuatan aneka produk kerajinan tenun dari limbah lidi kelapa sawit kepada remaja yang berdomisili di kampung Paya Bedi dan sekitarnya

c. Diversifikasi produk kerajinan tangan dari limbah lidi kelapa sawit (kerajinan tangan menjadi kerajinan tenun berbahan lidi sawit)

d. Penguatan tatakelola administrai bisnis dan keuangan kelompok perempuan Karya Muda

\subsection{Target Luaran}

Luaran yang ditargetkan pada program pelatihan ini meliputi:

1. Optimalisasi penggunaan ATBM oleh kelompok karya muda menjadi:

a. anggota kelompok akan semakin sering dan lancar dalam menggunakan ATBM sehingga menghasilkan produk kerajinan yang ekonomis dan artistik

b. menggalakan remaja putri agar lebih puduli lingkungan dan membuka lapangan pekerjaan dalam bingkai kewirausahaan melalui pelatihan tenun limbah lidi kelapa sawit kepada remaja putri putus sekolah dan yang aktif sekolah (paruh waktu)

c. penciptaan varian produk tenun limbah lidi sawit menjadi beraneka produk kerajinan tangan seperti kotak tisu, kotak asesories, dompet dan tas tangan wanita dan lain-lain.

d. anggota kelompok mampu menerapkan tata kelola administrasi bisnis dan pembukuan kelompok secara benar dan akurat.

\section{METODE PELAKSANAAN}

\subsection{Kerangka Konsep Penyelesaian Masalah}

Berdasarkan permasalahan diidentifikasi di atas maka metode pendekatan yang digunakan adalah metode apprenticeship yaitu dengan cara memberikan bimbingan dan langsung mengerjakan. Mengingat keterbatasan kemampuan peserta untuk menelaah terlalu dalam mengenai materi yang diajarkan serta keterbatasan ATBM yang dimiliki kelompok karya muda. Dengan demikian cara yang paling praktis adalah dengan membagi peserta menjadi empat kelompok yang terdiri masing-masing 2 hingga 3 orang per kelompoknya dan didampingi oleh anggota mitra yang sudah mahir.

Kemudian untuk menghindari dari rasa jenuh dan bosan oleh remaja putri tersebut maka pelatihan ini dibagi ke dalam pembahasan. Adapun pembahasan pada hari pertama di mana materi yang disampaikan oleh Zulkarnen Mora berkenaan dengan Optimalisasi Penggunaan ATBM Kelompok. Pada hari kedua materi diberikan oleh Abdul Latief mengenai Pelatihan Tenun limbah lidi kelapa sawit dengan menggunakan ATBM. Pada hari terakhir materi diajarkan oleh Zanunddin mengenai Penguatan aspek manajemen bisnis dan keuangan kelompok Perempuan Karya Muda.
Pelatihan ketrampilan, pelatihan manajemen usaha, dan pendampingan, metode pendekatan untuk memecahkan masalah mitra sebagai berikut :

1. Pelatihan mengoptimalakan penggunaan ATBM kepada anggota kelompok

2. Pelatihan tenun limbah lidi kelapa sawit kapada remaja putri putus sekolah dan yang masih sekolah dan berminat dalam kewirausahaan dengan menggunakan ATBM

3. Penguatan kemampuan menguasai tata kelola bisnis dan pembukuan anggota kelompok karya muda.

Materi pelatihan yang diajarkan adalah :

- Pelatihan memperlancar anggota tubuh (tangan dan kaki) dalam menggunakan ATBM sekaligus menghasilkan bahan dasar tenunan.

- Pelatihan ketrampilan pembuatan kotak tisu dan kotak asesories dari limbah lidi kelapa sawit.

- Pelatihan ketrampilan pembuatan dompet dan tas tangan wanita dari limbah lidi kelapa sawit.

- Pelatihan mengenal bentuk-bentuk usaha kecil dan koperasi

- Pengenalan jaringan distribusi dengan mitra bisnis yang ada di pasar

- Menentukan harga jual

\section{HASIL DAN PEMBAHASAN}

Kegiatan pelatihan ketrampilan bagi kelompok perempuan Karya Muda dilaksanakan di Galeri Kelompok Karya Muda, Kampung Paya Bedi, Kecamatan Rantau, Kabupaten AcehTamiang. Pelatihan ini dimulai tanggal 4 s.d 7 Agustus 2017. Kegiatan ini meliputi: Sosialisasi kegiatan, pelatihan optimalisasi ATBM kepada anggota kelompok karya muda dengan memanfaatkan limbah lidi kelapa sawit, pelatihan tenun limbah lidi kelapa sawit kepada remaja putri dan pelatihan pengelolaan tata kelola usaha bisnis dan pembukuan anggota kelompok karya muda.

Pelatihan ini lebih difokuskan pada penciptaan produk yang berbasis limbah dari lidi kelapa sawit yang tidak terpakai/ terbuang percuma baik dari kebun perusahaan maupun kebun warga sekitar. Sehingga diharapkan produk kerajinan tangan yang dihasilkan dapat bernial jual dan penuh dengan nilai seni sehingga baik remaja putri putus sekolah maupun anggota kelompok karya muda mampu menghasilkan image kampung melalui produk unggulan yang berbasis one product onve village. Selain itu produk kerajinan tangan yang dihasilkan oleh remaja putri ini kiranya dapat dijual baik ke pasar lokal muapun pasar antar daerah melalui agenageb distributor maupun ajang pameran (expo yang sifatnya temporer).

\section{Sosialisasi kegiatan pelatihan}

Sosialisasi kegiatan dilaksanakan pada hari Jumat, tanggal 4 Agustus 2017 bertempat di Pusat belajar Kelompok Karya Muda Paya Bedi. Kec. Rantau. Pada pukul 14.00 - 17.00 WIB. Sosialisasi kegiatan 
di hadiri oleh Kepala Desa/ Datuk Paya Bedi, Perangkat Desa, anggota Kelompok Karya Muda dan remaja putri serta masyarakat Kampung Paya Bedi. Hasil sosialisasi disepakati jadwal dan mekanisme pelatihan tenun limbah lidi Kelapa Sawit untuk remaja putri dan kelompok perempuan karya muda di Kampung Paya Bedi.

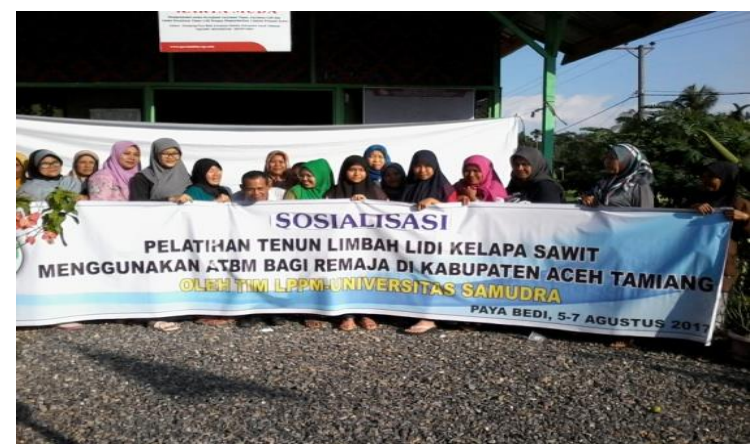

Gambar2. Sosialisasi Kegiatan Pengabdian

Kegiatan pelatihan dimata pemerintahan kampung Paya Bedi merupakan satu hal yang membantu warganya dari masalah kesenjangan ekonomi dan perbaikan pendapatan keluarga. Kemudian diharapkan dari pelatihan ini lebh banyak penciptaan lapangan kerja serta tergagas ekonomi kreatif bagi generasi muda saat ini. Dengan adanya tanggapan positif dari mitra kegiatan diharapkan dapat berjalan lancar, sehingga semua program pelatihan berjalan sesuai dengan waktu yang telah disepakati. Langkah berikutnya setelah dilakukan sosialisasi yaitu mengadakan pelatihan tenun dari limbah lidi kelapa sawit dengan berbagai macam ragam produk hasil tenun.

\section{Pelatihan Mengopitmalkan Penggunaan ATBM Oleh Anggota Kelompok Karya Muda}

Pelatihan ini menganut metode apprenticeship yaitu dengan cara memberikan bimbingan dan langsung mengerjakan. Pada permulaannya peserta diminta untuk menyiapkan benang tenun dan Lidi Kelapa Sawit yang sudah halus sebagai bahan utama. Agar lebih efektif jalannya pelatihan ini para peserta dibagi menjadi 4 kelompok, tiap kelompok terdiri dari 2-3 orang peserta. Setiap kelompok didampingi oleh 1 orang intsruktur/ pemateri.

Proses menggunakan ATBM ini oleh kelompok dimana setiap peserta ditunjukkan sistematika kerja alat tenun ini dengan lebih mengandalkan kemahiran tangan serta goyangan kaki untuk mengunci lidi yang akan ditenun natninya. Tentunya salah seorang dari peserta lainnya telah menempatkan benang tenun ke dalam ATBM tersebut pengarahan demi pengarahan disampaikan secara bertahap oleh pemateri/ instruktur agar peserta benar-benar memahmi fungsi ATBM ini dan diupayakan tidak salah langkah. Jika langkah yang diajarkan tidak benar dipahami oleh peserta maka kedudukan lidi yang ditenun tidak rapat/kuat sehingga hasilnya tidak dapat dibentuk untuk menjadi produk kerajinan tenun yang berkualitas. Oleh karena itu baik pemateri/ instruktur memberikan instruksi dengan sangat sabar karena dimaklumi sekali di mana anggota kelompok karya muda belum pernah menggunakan ATBM sebelumnya. Kemudian tahapan ini terus dilakukan secara berulang-ulang dan berganti-gantian dalam keadaan relek.
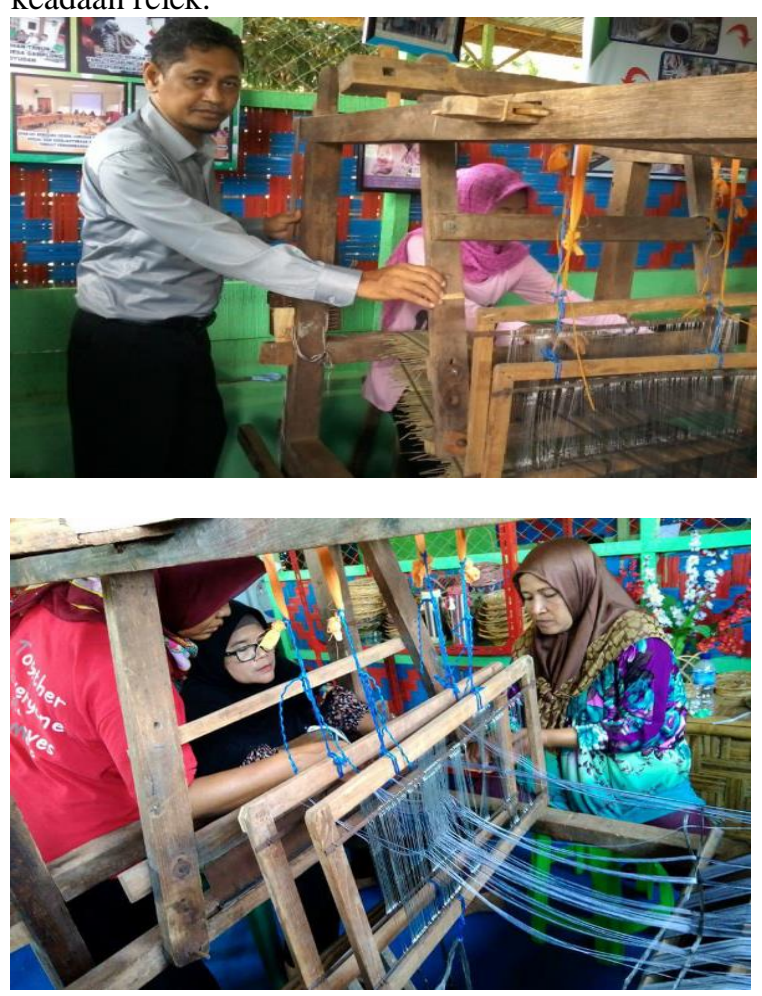

Gambar 3. Instruktur sedang memberikan penjelasan penggunaan ATBM secara optimal

Pelatihan Tenun Limbah Lidi Kelapa Sawit Dengan Menggunakan ATBM Oleh Remaja Putri Pada pelatihan ini pemateri menerapkan metode apprenticeship yaitu dengan cara memberikan bimbingan dan langsung mengerjakan sehingga kelihatannya para remaja putri lebih menggebu-gebu dalam menggunakan ATBM tersebut dikarenakan tingkat kesabaran yang mereka miliki masih kurang. Terlihat beberapa kali para pserta harus minta terus dibimbing oleh instruktur/pemateri karena kejanggalan mereka dalam menggunakan alat tenun tersebut. Beberapa kali hasil tenun yang didapati rusak dan dibongkar kembali. Hal ini yang membuat peserta menjadi jengkel dan bosan. Oleh karena itu materi pelatihan ini agak memakan waktu yang lama agar dihasilkan kerajinan tenun yang lebih rapi dan bagus.

Pada sesi lanjutan setelah hasil tenunan diperoleh maka tahapan lanjutannya adalah membuat mal produk seperti menyiapkan karton, pisau kater dan gunting lidi serta lem merk banteng. Tujuannya adalah setelah lidi sawit yang telah ditenun tadi dapat dibentuk menjadi kotak tisu, dompet wanita dan kotak asesories serta kotak stationery. Pada tahapan 
ini kelihatan para pesrta lebih enjoy karena tidak terlalu tegang perasaanya seperti pada saat menenun dengan menggunakan ATBM.

Hasil akhir yang diperoleh ternyata masih banyak produk yang belum rapi karena waktu yang sempit dan kesabaran mereka yang masih rendah. Dengan demikain diharapkan peserta dapat bergabung dengan kelompok karya muda supaya mereka lebih sering menggunakan ATBM sehingga menjadi lancar.

Dalam kesempatan ini instruktur menyarankan kepada peserta pelatihan bahwa dalam menenun lidi harus benar-benar rapat dan kuat sehingga pada saat dibentuk/dibuat kotak tisu dan yang liannya menjadi lebih elegan dan artistik.

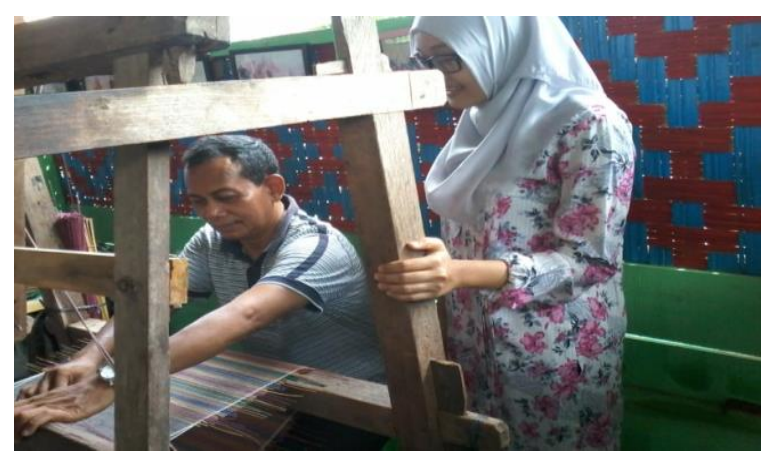

Gambar 4. Instruktur menjelaskan langkah menenun limbah lidi kelapa sawit dengan menggunakan ATBM kepada ramaja putri

Adapun teknik menenun lidi sawit dan pembentukan kotak tisu dan kotak asesories adalah:

a) Menyiapkan benang tenun ke ATBM dari gulungan benang/tungkul nya,

b) Ambil lidi 10 batang lidi sawit dan diikatkan menjadi satu ikat kecil untuk ditenun menjadi bahan dasar kerajinan tenun nantinya,

c) setelah ATBM siap maka masukkan 1 batang lidi kemudian dirajut dengan benang yang ada di roda/gulungan ATBM dan selanjutnya dikunci dengan menggunakan hentakan kaki (pedal) pada ATBM. Gerakan ini dilakukan secara terus-menerus dengan memasukkan lidi selanjutnya ke ATBM sampai menjadi seperti alas yang panjang,

d) jika ingin mendapatkan hasil tenun yang berwarna warni bisa diselingi dengan lidi yang telah diwarnai ataupun benang lain yang berwarna pula sehingga menghasilkan tenunan yang indah dan menarik,

f) Setelah tenunan selesai maka tindakan lanjutan adalah mengukur dan merancang format atau bentuk yang akan direncanakan dibuat contoh, kotak tisu,

g) untuk membentuk format atau fitur yang dirancang perlu disiapkan gunting potong lidi, penggaris besi, kapur kain, gunting, lem cap banteng dan karton ubi sebagai alas/ dasar tulangnya serta asesories lain yang dianggap menarik,

h) Setelah siap digambarkan coraknya lalu dipotong dengan gunting lidi sesuai dengan mal yang telah dirancang sebelumnya. Pada bagian ini dibuat terlebih dahulu dudukan bawah kotak tisu dengan bentuk bujur sangkar atau persegi panjang sesuai dengan selera konsumen. Kemudian jika telah selesai tahapan pertama maka dilanjutkan dengan menyiapkan tutup kotak tisu atas. Pada bagian ini perlu dipotong tengah dari kotak atas ini supaya tisu yang akan diletakkan dapat diarik satu persatu. Hal yang sama juga dilakukan dengan membentuk pola bujur sangkar atau persegi panjang.

j) Setelah kedua belah kotak selesai maka pada sisi dalam diberikan les atau kain tepi supaya nampak batasan koaknya dan kotak lebih erat agar tidak jatuh atau lepas dari dudukan kotak tisunya. Kain tepi tadi harus diberi lem cap banteng agar melekat dan tidak cepat terkelupas dari kotak asalnya,

k) bila tahapan ini selesai ada baiknya kedua kotak tisu yang dibuat tadi perlu dijemur sebentar agar lem merekat lebih kokoh dan sambil mempersiapkan asesories lainya yang dianggap perlu untuk memperindah produk tadi,

1) jika kedua belah kotak tisu tadi cukup kering maka tindakan selanjutnya memasang asesories atau pernak-pernik yang kelihatannya menarik dan indah,

h) tahapan akhir agar kotak tisu tersebut lebih terjaga kebersihannya maka diperlukan packiging dengan pelastik pembungkus serta berikan label sebagai trade mark.
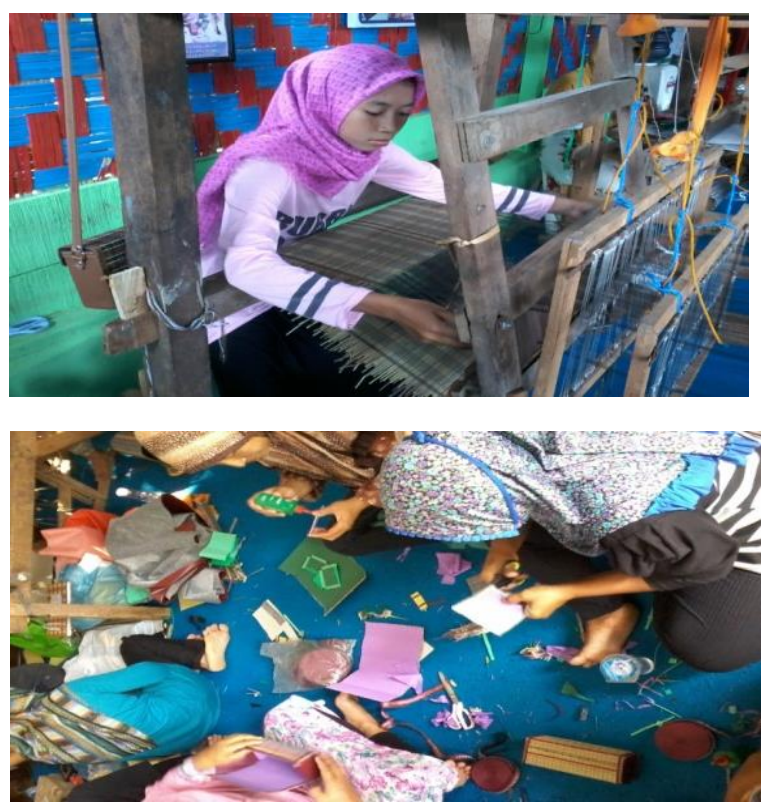

Gambar 5. Salah seorang peserta sedang menenun lidi kelapa sawit dan instruktur mengajarkan peserta membentuk hasil tenunan menjadi kotak tisu 
Pelatihan Tata Kelola Bisnis Dan Pembukuan Kelompok Karya Muda

Pada pelatihan tahap akhir ini pemateri menerapkan metode ceramah kepada setiap anggota yang diajarkan bagaimana menata bisnis dimulai dengan menghitung modal dasar untuk sebuah produk kerajinan tenun. Peserta dilatih menghitung harga pokok penjualan dengan cara menghitung biaya yang dikeluarkan untuk membeli bahan baku seperti benang tenun dengan berbagai warna, peralatan pendukung tenun seperti gunting potong lidi, penggaris besi dan pisau cutter. Kemudian menghitung bahan habis pakai seperti kain pinggiran, kapur kain, lem cap banteng serta asesories lainya serta jarum renda pinggir tenunan. Kemudian setelah memahami cara menghitung harga pokok penjualan maka dilanjutkan dengan menghitung laba atau keuntungan usaha. Dengan demikian peserta mulai mengerti berapa modal dan kewajiban kelompok dengan mengurangi selisih dari masing-masing item untuk perhitungan laba atau rugi usaha.

Selanjutnya anggota kelompok diajarkan bentukbentuk usaha yang bisa dibentuk atau diterapkan supaya anggota bisa membentuk jenis-jenis usaha yang sesuai dengan pemahan anggota dan diterapkan.
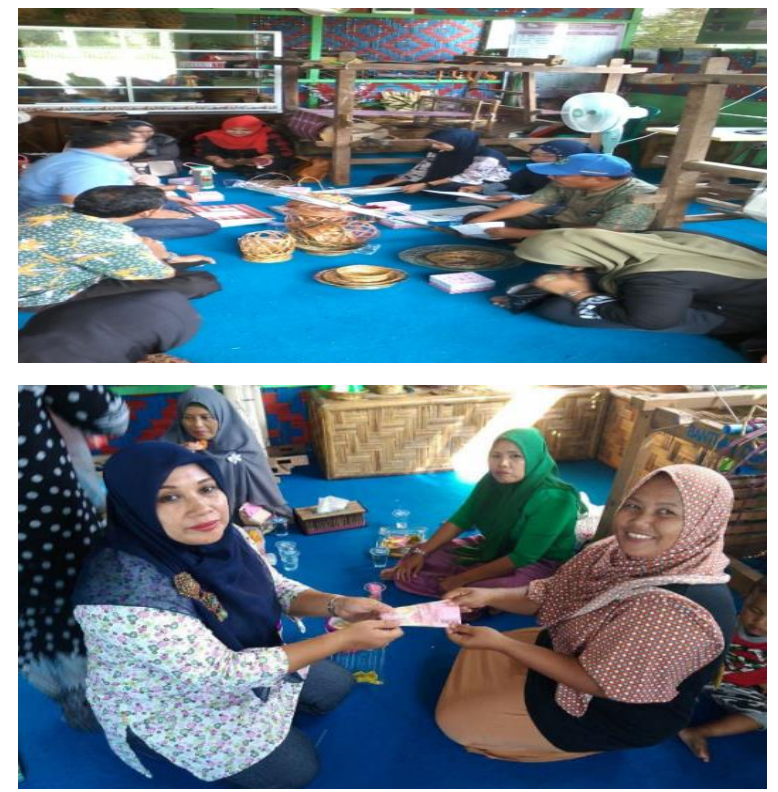

Gambar 6. pelatihan tata kelola bisnis dan pembukuan bagi kelompok Perempuan Karya Muda

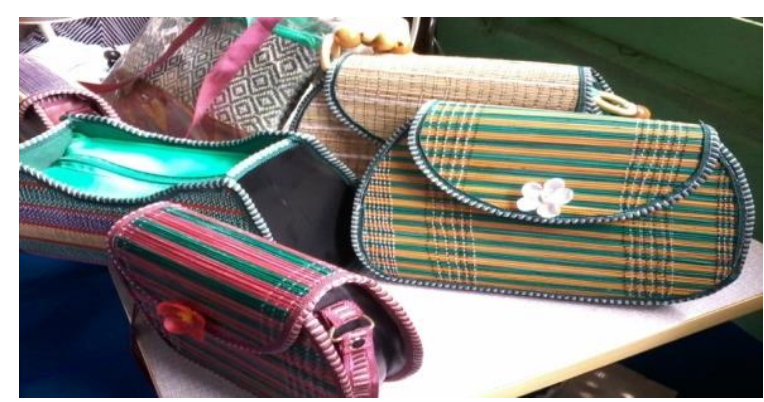

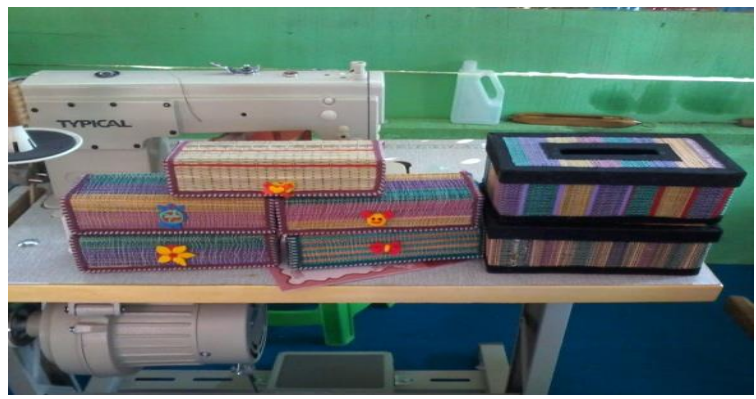

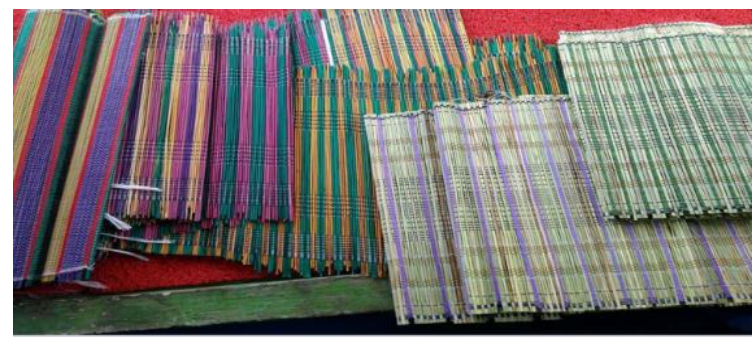

Gambar 7. Finishing serta varian produk yang dihasilkan peserta dan kelompok perempuan Karya Muda berupa tas wanita, kotak tisu dan kotak asesories

\section{KESIMPULAN}

1. Setiap anggota kelompok karya muda mulai menguasai cara menggunakan ATBM dengan benar tentunya harus sering-sering melakukan praktek di pusat belajar kelompok karya muda. Di samping itu mereka telah menguasai menenun lidi kelapa sawit yang tadinya berupa limbah kini sudah dapat dimanfaatkan sebagai produk kerajinan yang bernilai ekonomis dan artistik.

2. Setiap remaja putri yang mengikuti pelatihan ini telah memahami bahwa limbah lidi kelapa sawit dapat dijadikan sebagai produk bernilai jual. Di samping itu untuk memenuhi keperluan sehari-hari sudah dapat diperoleh sendiri dengan berwirausaha yang berbasis ramah lingkungan dengan mengurangi ketergantungan dari pihak keluarga.

3. Anggota kelompok karya muda telah mengerti jenis-jenis usaha bisnis yang bisa mereka jalankan untuk keberlangsungan bisnis seperti usaha dagang dan koperasi wanita. Kemudian mereka juga telah memahami tentang cara menghitung harga pokok penjualan dan laba usaha dan telah memiliki pembukuan yang baik.

4. Produk kerajinan yang dihasilkan kelompok karya muda mulai sudah muali beragam jenisnya dan tampilan kemasan pun sudah kelihatan elegan dan artistik untuk dijula ke pasar serta sudah berani untuk ikut kegiatan pameran yang diselenggarakan oleh pihak-pihak tertentu.

\section{UCAPAN TERIMA KASIH}

Penulis mengucapkan terima kasih kepada Lembaga Penelitian, Pengabdian dan Penjaminan Mutu Universitas Samudra untuk kegiatan PKM tahun 
2017. Penulis juga mengucapkan terima kasih kepada Rektor Universitas Samudra, Pemerintah Kabupaten Aceh Tamiang, dan Datuk Penghulu Kampung Paya Bedi serta seluruh anggota kelompok karya muda.

\section{DAFTAR PUSTAKA}

Badan Pusat Statistik. Rantau Dalam Angka Tahun 2014 (PDF), Aceh Tamiang: BPS Kabupaten Aceh Tamiang

Balai Informasi Pertanian, 1990. pada http://www. litbang.deptan.go.id. tanggal akses $10 \mathrm{Mei}$ 2016

Creswell, John W. 2003. Research Design Qualitative, Quantitative and Mixed Methods Approach (2 ${ }^{\text {nd }}$ Edition). University of Nebraska. Sage Publication

Direktorat Jenderal Perkebunan. 2008. Pada ditjenbun.pertanian.go.id tanggal akses $10 \mathrm{Mei}$ 2016

Dokumen Rencana Kerja Kelompok Perempuan Anyaman Tepas Karya Muda Tahun 20142018

http://elearning.unej.ac.id/courses/PNU1705/docume nt/babIklpswt.doc?cidReq=PNU1705 diakses tanggal 10 Mei 2016

http://www.lintasatjeh.com/2015/06/terobosan-bijakala-camat-cantik-rantau.html diakses tanggal 9 Agustus 2017

Sastrosayono, S. 2003. Budidaya Kelapa Sawit. Jakarta: Agromedia Pustaka

Setyamidjaja, D. 2006. Kelapa Sawit. Yogyakarta: Kanisius

Sunarko. 2007. Petunjuk Praktis Budidaya \& Pengolahan Kelapa Sawit. Jakarta: Agromedia Pustaka 